

\title{
Association between polymorphisms in exons 4 and 10 of the $B P I$ gene and immune indices in Sutai pigs
}

Z.C. Wu ${ }^{1}$, Y. Liu ${ }^{1}$, Q.H. Zhao ${ }^{1}$, S.P. Zhu ${ }^{1}$, Y.J. Huo ${ }^{1}$, G.Q. Zhu' ${ }^{2}$, S.L. Wu ${ }^{1}$ and W.B. Bao ${ }^{1}$

${ }^{1}$ College of Animal Science and Technology,

Key Laboratory for Animal Genetics, Breeding,

Reproduction and Molecular Design of Jiangsu Province,

Yangzhou University, Yangzhou, China

${ }^{2}$ College of Veterinary Medicine, Yangzhou University,

Yangzhou, Jiangsu, China

Corresponding authors: W.B. Bao / S.L. Wu

E-mail: wenbinbao74@yahoo.com / slwu@yzu.edu.cn

Genet. Mol. Res. 14 (2): 6048-6058 (2015)

Received January 12, 2014

Accepted January 19, 2015

Published June 8, 2015

DOI http://dx.doi.org/10.4238/2015.June.8.2

ABSTRACT. The bactericidal/permeability-increasing protein $(B P I)$
gene has been identified as a candidate gene for disease-resistance
breeding. We evaluated whether polymorphisms in exons 4 and 10 of
the $B P I$ gene are associated with immune indices [interleukin-2 (IL-
2), IL-4, IL-6, interferon- $\beta$ (IFN- $\beta$ ), IL-10, and IL-12]. In this study,
we identified one mutation (C522T) in the BPI exon 4 site and two
mutations (A1060G and T1151G) in the BPI exon 10 site. Correlation
analysis revealed that in the Sutai pig population, the effect of genotypes
at the BPI exon 4 site on the level of IL-6 was significant (P $<0.05$ ),
with an effective genotype of CD; moreover, the effect of genotypes at
the $B P I$ exon 10 site on the level of IL-12 was significant (P $<0.05)$,
and the effective genotype was AB. The optimal combined genotype
was CD-AB, which was more effective regarding the IL- 6 and IL-12 
levels compared to the other combined genotypes $(\mathrm{P}<0.05)$. These results indicate that single nucleotide polymorphisms and the combined genotypes of BPI exons 4 and 10 affect immune indices in Sutai pigs. Therefore, these genotypes should be further examined as effective markers for disease-resistant breeding of pigs.

Key words: $B P 1$ gene; Combined genotype; Immune indices; Pig; Single nucleotide polymorphisms

\section{INTRODUCTION}

Bactericidal/permeability-increasing protein (BPI) belongs to the lipopolysaccharide (LPS)-binding protein family. It is an endogenous cationic protein present in humans and other mammals and is primarily present in the aniline blue-staining particles of polymorphonuclear leukocytes. BPI not only kills Gram-negative bacteria and neutralizes endotoxins and LPS (Akin et al., 2011), but also promotes complement activation and opsonization for increased phagocytosis, inhibits angiogenesis, inhibits inflammatory mediator release, and inhibits infection by fungi and protozoa. Therefore, BPI plays a key role in the natural defense system of the animal body (Weiss et al., 1978; Elsbach, 1998). The function of BPI is related to its structure, which includes a cationic, lysine-rich N-terminus with antibacterial and LPS (endotoxin)-neutralizing activities (Iovine et al., 1997) and a C-terminus that improves stability and opsonic activity (Ooi et al., 1991). Binding of the BPI protein to the negatively charged LPS envelope activates the mononuclear phagocyte system, leading to the release of cytokines such as tumor necrosis factor- $\alpha$, interleukin (IL)-6, and IL-2, which contribute to the subsequent inflammatory reaction (Mannion et al., 1989). Under normal physiological conditions, specific immune indices reflect the overall immune reaction activity involved in disease resistance (Ma et al., 2011).

The porcine $B P I$ gene is located at 7q21-23 and consists of 15 exons and 14 introns (Shi et al., 2003). Recent studies have shown that polymorphisms are present in the porcine $B P I$ gene and have demonstrated their impact on disease resistance/susceptibility. Shi et al. (2003) reported that polymorphisms in exon 4 of the BPI gene in York, Pig Improvement Company (PIC), and Meishan pigs were related to resistance against Salmonella infection. Moreover, Christopher et al. (2004) reported that the AvaII and HpaII restriction fragment length polymorphism (RFLP) sites in exons 4 and 10 of $B P I$ were related to susceptibility to Salmonella infection. Some single nucleotide polymorphism (SNP) sites in the BPI gene may be important molecular markers of porcine disease resistance, specifically resistance against Gram-negative bacteria $(\mathrm{Cao}, 2008)$. Based on these and other findings, BPI was identified as a candidate gene for disease-resistance breeding.

Enterotoxigenic Escherichia coli and Salmonella spp are the main Gram-negative bacteria found in the swine intestine. Previous research has shown that the BPI gene is related to the susceptibility to Salmonella infection; we found that genetic variation in exon 10 of the $B P I$ gene is associated with $E$. coli F18 (Liu et al., 2013). To determine whether the BPI gene is an effective marker for anti-disease breeding, we detected polymorphisms in exons 4 and 10 in the BPI gene. Important immune indices were assessed using an enzyme-linked immunosorbent assay, and the effect of single genotypes and combined genotypes of the BPI gene on immune indices were analyzed. In this study, we examined the effect of polymorphisms in the 
$B P I$ gene and provided a theoretical basis for genetic marker selection for resistance against Gram-negative bacteria.

\section{MATERIAL AND METHODS}

\section{Experimental materials}

Sutai pigs $(\mathrm{N}=196)$ from 10 lineages were provided by the Jiangsu Engineering Research Centre for Molecular Breeding of Pigs located in Suzhou city. Approximately $1.0 \mathrm{~g}$ ear tissue was collected from each individual and stored in a $1.5-\mathrm{mL}$ microcentrifuge tube in an icebox. DNA was extracted using the conventional phenol-chloroform method and stored at $-20^{\circ} \mathrm{C}$ for later use.

\section{Polymerase chain reaction (PCR)-single-strand conformation polymorphism (SSCP)/RFLP analysis}

The BPI mRNA sequence (accession No. EF436278) and genomic sequence (accession No. FP339579.2) were obtained from the Spidey database (http://www.ncbi.nlm.nih.gov/IEB/ Research/Ostell/Spidey/). The 15 exon sequences for the BPI gene were determined using the genomic sequence obtained. Using the Primer Premier 5.0 software, primers were designed based on the acquired sequences (Table 1). The primers were synthesized by Shanghai Biological Engineering Technology Co. Ltd. (Shanghai, China). The amplification reaction system consisted of $2.5 \mu \mathrm{L} 10 \mathrm{X}$ PCR buffer, $1.5 \mu \mathrm{L} 2.5 \times 10^{3} \mu \mathrm{M}$ dNTPs, $1 \mu \mathrm{L} 10 \mu \mathrm{M}$ primers (upstream), $1 \mu \mathrm{L} 10 \mu \mathrm{M}$ primers (downstream), $0.2 \mu \mathrm{L} \mathrm{Taq}$ enzyme $(5 \mathrm{U} / \mu \mathrm{L})(\mathrm{TaKaRa}$ Biotechnology Dalian Co. Ltd., Shiga, Japan), $1 \mu \mathrm{L} 100 \mathrm{ng} / \mu \mathrm{L}$ DNA template, and $17.8 \mu \mathrm{L}$ $\mathrm{ddH}_{2} \mathrm{O}$; the total volume was $25 \mu \mathrm{L}$. The PCR amplification program consisted of denaturation at $94^{\circ} \mathrm{C}$ for $4 \mathrm{~min}, 32$ cycles of denaturation at $94^{\circ} \mathrm{C}$ for $30 \mathrm{~s}$, annealing (specific temperatures are shown in Table 1) for $30 \mathrm{~s}$, and extension at $72^{\circ} \mathrm{C}$ for $30 \mathrm{~s}$, followed by a final extension at $72^{\circ} \mathrm{C}$ for $7 \mathrm{~min}$; the reaction was held at $4^{\circ} \mathrm{C}$.

Table 1. Primer sequences for BPI exons 4 and 10.

\begin{tabular}{|c|c|c|c|}
\hline Primer & Primer sequence & Annealing temperature $\left({ }^{\circ} \mathrm{C}\right)$ & Expected length (bp) \\
\hline Exon 4 & $\begin{array}{l}\text { F: 5'-TCAGGTTGGTTACCGCAGAG-3' } \\
\text { R: 5'-ACCCTGTTGATGTGGCTTCT-3' }\end{array}$ & 62.4 & 200 \\
\hline Exon 10 & $\begin{array}{l}\text { F: 5'-CCCAACATGGAGATGCAGTTC-3' } \\
\text { R: 5'-CAATGAATCAATGAGCACACC-3' }\end{array}$ & 57.0 & 445 \\
\hline
\end{tabular}

For PCR-SSCP analysis of the BPI exon $4,4 \mu \mathrm{L}$ of each PCR product was mixed with $7 \mu \mathrm{L}$ denaturing loading buffer $(0.05 \%$ xylene-cyanide, $0.05 \%$ bromophenol blue, and $5.5 \mathrm{mM}$ EDTA, $\mathrm{pH} 8.0$, in formamide), denatured at $98^{\circ} \mathrm{C}$ for $15 \mathrm{~min}$, and snap-chilled on ice for at least $5 \mathrm{~min}$. Samples were then loaded onto $12 \%$ polyacrylamide gels (acrylamide:bisacrylamide $=29: 1$ ) and electrophoresed at a constant voltage of $110 \mathrm{~V}$; the gel was stained with silver and visualized under ultraviolet light.

For PCR-RFLP analysis of the BPI exon $10,10 \mu \mathrm{L}$ of each PCR product was digested overnight at $37^{\circ} \mathrm{C}$ using the $\mathrm{HpaII}(5 \mathrm{U} / \mu \mathrm{L})$ restriction enzyme. Digested fragments were 
electrophoresed on $10 \%$ polyacrylamide gels in $1 \mathrm{X}$ tetrabromoethane at a constant voltage of $120 \mathrm{~V}$, stained with silver, and visualized under ultraviolet light. For sequencing, SNPs in BPI exons 4 and 10 were detected by sequence alignment using DNAMAN version 5.0 (Lynnon Biosoft, Quebec, Canada).

PCR products were extracted using a gel extraction kit (Bio Basic, Inc., Quebec, Canada) and sequenced using the ABI PRISM 377 DNA auto sequencer (Shanghai Biotechnology Co. Ltd., Shanghai, China).

\section{Determination of immune indexes}

Jugular venous blood was collected from 35-day-old weaning piglets. EDTA was used as an anticoagulant. Blood serum was separated using conventional methods, including centrifugal separation at 2000-3000 rpm. Sample absorbance was determined using an enzymelinked immunosorbent assay kit (R\&D Systems, Minneapolis, MN, USA). The absorbance values were used to draw the standard curve, which was used to measure the following 6 indices: IL-2, IL-4, IL-6, interferon- $\beta$ (INF- $\beta$ ), IL-10, and IL-12.

\section{Statistical analyses}

The frequencies of the gene and genotypes were calculated according to Hardy-Weinberg equilibrium principle: $p=\mathrm{P}+\mathrm{H} / 2, q=\mathrm{Q}+\mathrm{H} / 2, \chi^{2}=\sum \mathrm{d}^{2} / \mathrm{e}$. In this equation, $d=\mathrm{e}-\mathrm{o}$, which is the difference between the predicted value and the detected value; $p$ and $q$ represent the allele frequencies at specific positions; $P$ and $Q$ represent the homozygote frequency at certain positions; $H$ represents the heterozygote frequency at different positions; $\chi^{2}$ represents chi-square value. The general linear model was established using the SPSS version 18.0 software (SPSS, Inc., Chicago, IL, USA) to analyze the effects of the genotypes at BPI exons 4 and 10 on measured traits. The following linear models were used:

Model 1: $Y_{i j}=\mu+$ Genotype $_{i}+e$

Model 2: $Y=\mu+$ Genotype $_{B P \text { I exon } 4}+$ Genotype $_{B P I \text { exon 10 }}+$ Genotype $_{B P I \text { exon 4-BPI exon 10 }}+e$ $Y_{i j}$ represents the measured traits; $\mu$ represents the overall mean; Genotype ${ }_{i}$ is the genotypic effect at $B P I$ exon 4 or $B P I$ exon 10; and $e$ is the residual error.

\section{RESULTS}

\section{PCR-SSCP analysis of the BPI exon 4}

A clear DNA band was observed at $200 \mathrm{bp}$; this was in agreement with the predicted amplified fragment size. SSCP analysis indicated that there were 3 genotypes: $\mathrm{CC}, \mathrm{CD}$, and DD. The electrophoresis map is shown in Figure 1.

\section{PCR-RFLP analysis of the BPI exon 10}

A clear DNA band was observed at $445 \mathrm{bp}$; this was in agreement with the predicted amplified fragment size. A restriction enzyme recognition site for HpaII was present in the $B P I-10$ gene, which was completely digested by HpaII to produce the BB phenotype (304/142 
bp). If this position contained a $\mathrm{B} \rightarrow \mathrm{A}$ mutation, the HpaII enzyme was unable to digest the fragment, resulting in the AA phenotype (445 bp). When both alleles existed together, they produced the AB type (445/304/142 bp). The restriction map is shown in Figure 2.

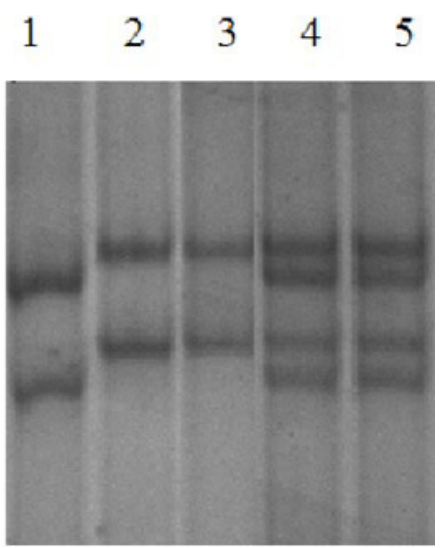

Figure 1. SSCP electrophoresis patterns of PCR products at exon 4 of the BPI gene. Lane $1=\mathrm{DD}$ type; lanes 2 and $3=\mathrm{CC}$ types; lanes 4 and $5=\mathrm{CD}$ types.

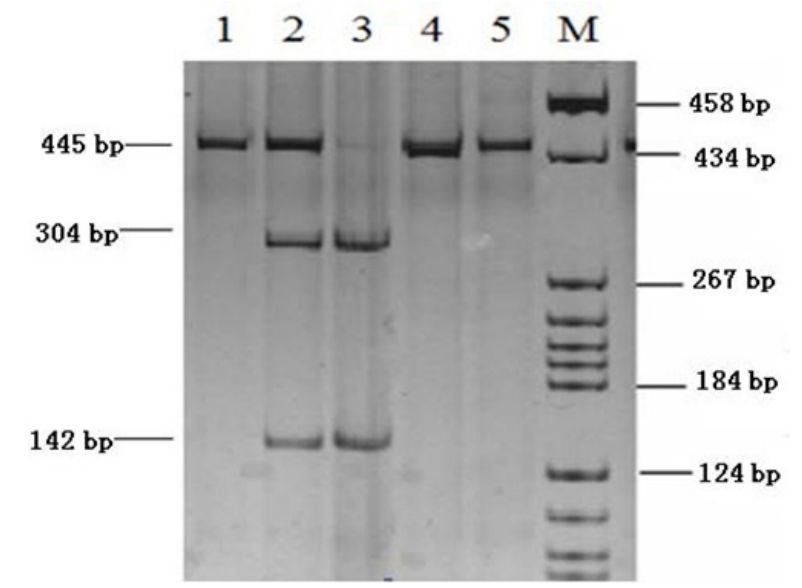

Figure 2. RFLP electrophoresis patterns of PCR products at exon 10 of the BPI gene. Lanes 1, 4, and $5=\mathrm{AA}$ types; lane 2 = BB type; lane $3=\mathrm{AB}$ type; lane $M=\mathrm{pUC} 19 \mathrm{DNA} /$ Msp I (Hap II) marker.

\section{Sequence analysis}

\section{Sequencing of the BPI exon 4}

Sequence analysis of the PCR products of genotypes CC and DD revealed that the sequence of genotype CC corresponded to the sequence provided in GenBank (EF436278); however, genotype DD contained a $\mathrm{C} \rightarrow \mathrm{T}$ mutation at the 522-bp position, which did not result in an amino acid change. The sequencing map is shown in Figure 3. 

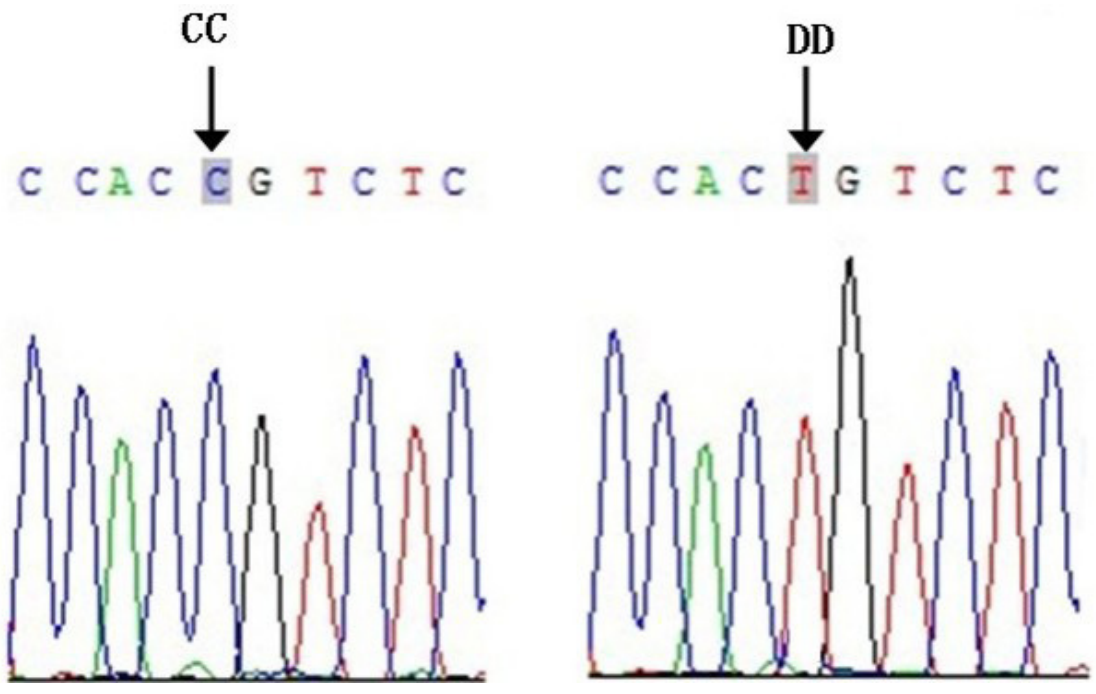

Figure 3. Sequencing results at exon 4 of BPI c.522 C $>\mathrm{T}$ locus.

\section{Sequencing of the BPI exon 10}

Sequence analysis of the PCR products for genotypes AA and BB showed that the sequence of genotype AA corresponded with the sequence provided in GenBank (EF436278). However, genotype $\mathrm{BB}$ contained an $\mathrm{A} \rightarrow \mathrm{G}$ mutation at the 1060-bp position, resulting in an amino acid substitution (Thr353Ala), as well as a $\mathrm{T} \rightarrow \mathrm{G}$ mutation at the 1151-bp position, which also resulted in an amino acid substitution (Leu383Arg). The sequencing map is shown in Figures 4 and 5.
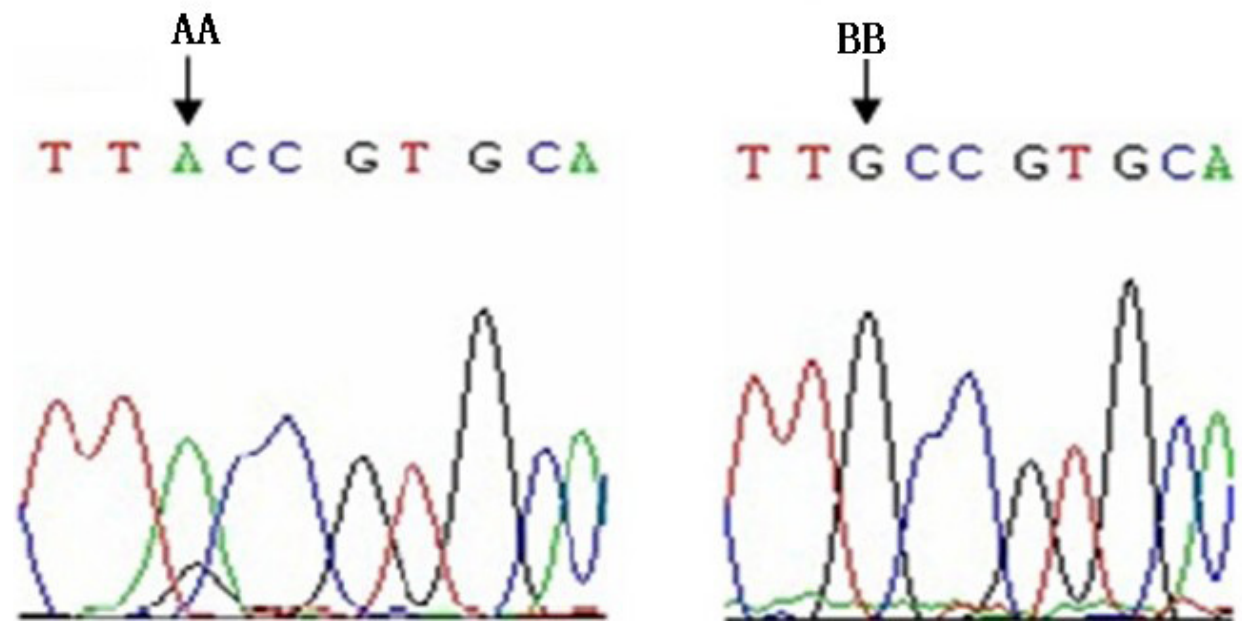

Figure 4. Sequencing results at exon 10 of $B P I$ c. $1060 \mathrm{~A}>\mathrm{G}$ locus. 

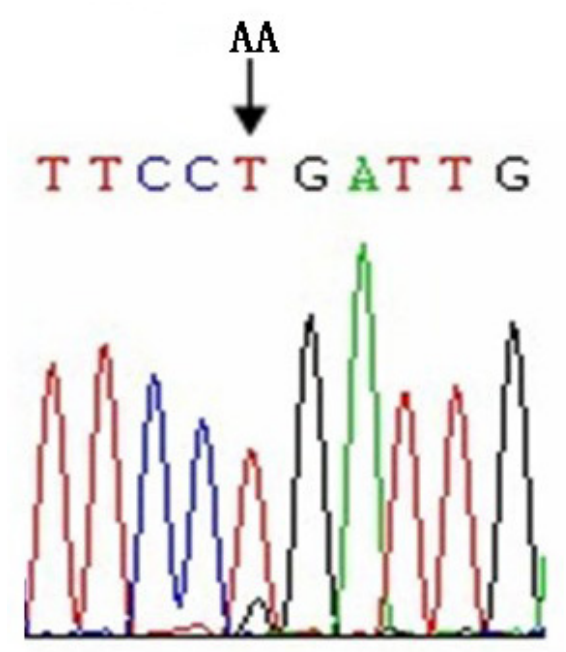

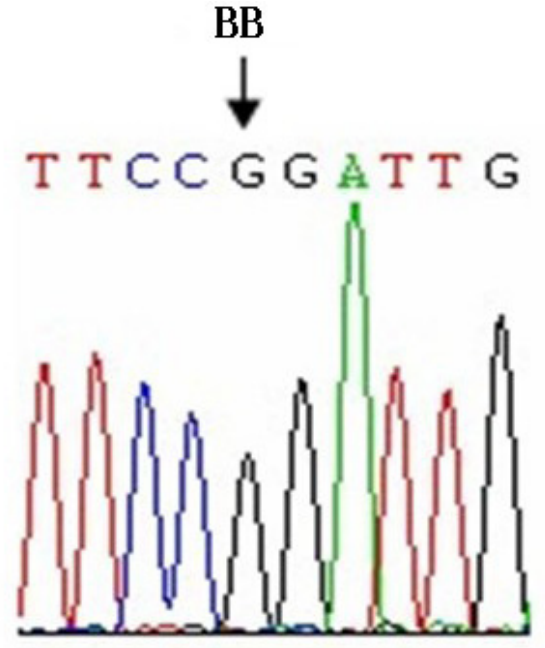

Figure 5. Sequencing results at exon 10 of $B P I$ c.1151 T $>$ G locus.

\section{Polymorphisms in BPI exons 4 and 10 in Sutai pigs}

Among the 196 Sutai pigs, 148 showed the CC genotype, 36 showed the CD genotype, and 12 showed the DD genotype at the BPI exon 4 site. The frequencies of the $\mathrm{CC}, \mathrm{CD}$, and DD genotypes were $0.755,0.184$, and 0.061 , respectively, and allele $\mathrm{C}$ was the dominant allele. The $\chi^{2}$ goodness-of-fit test showed that the sample was in genetic equilibrium $(\mathrm{P}>0.05$, Table 2).

The genotype distribution at the $B P I$ exon 10 site was as follows: 50, AA type; 106 , $\mathrm{AB}$ type; 40, $\mathrm{BB}$ type. The frequencies of the $\mathrm{AA}, \mathrm{AB}$, and $\mathrm{BB}$ genotypes were $0.255,0.541$, and 0.204 , respectively. The proportion of allele A was similar to that of allele B. According to the $\chi^{2}$ goodness-of-fit test, the sample showed significant deviation from Hardy-Weinberg equilibrium $(\mathrm{P}<0.05$, Table 2$)$.

Table 2. Genotype and allele frequencies at BPI exon 4 and 10 sites in Sutai pigs.

\begin{tabular}{|c|c|c|c|c|c|c|}
\hline Gene & & otype frequenc & & & & $\chi^{2}$ value \\
\hline$B P I$ exon 4 & $\begin{array}{l}\text { CC } \\
0.755(148)\end{array}$ & $\begin{array}{l}\text { CD } \\
0.184(36)\end{array}$ & $\begin{array}{l}\text { DD } \\
0.061(12)\end{array}$ & $\begin{array}{l}\mathrm{C} \\
0.847\end{array}$ & $\begin{array}{l}\mathrm{D} \\
0.153\end{array}$ & 8.331 \\
\hline$B P I$ exon 10 & $\begin{array}{l}\text { AA } \\
0.255(50)\end{array}$ & $\begin{array}{l}\mathrm{AB} \\
0.541(106)\end{array}$ & $\begin{array}{l}\text { BB } \\
0.204(40)\end{array}$ & $\begin{array}{l}\text { A } \\
0.526\end{array}$ & $\begin{array}{l}\text { B } \\
0.474\end{array}$ & 0.699 \\
\hline Combined genotype & $\begin{array}{l}\text { CCAA } \\
0.082(16)\end{array}$ & $\begin{array}{l}\text { CCAB } \\
0.388(76)\end{array}$ & $\begin{array}{l}\text { CCBB } \\
0.214(42)\end{array}$ & $\begin{array}{l}\text { CDAA } \\
0.163(32)\end{array}$ & $\begin{array}{l}\text { CDAB } \\
0.133(26)\end{array}$ & $\begin{array}{l}\text { DDAA } \\
0.020(4)\end{array}$ \\
\hline
\end{tabular}

The genotype quantity is shown in the parentheses, $\chi_{0.05}^{2}(1)=3.84, \chi_{0.01}^{2}(1)=6.64$.

\section{Relationship between the BPI exon 4 and 10 polymorphisms and immune indices}

There were no significant differences in the performance of 196 Sutai pigs from 10 lineages; thus, these pigs were analyzed without partition. With regard to BPI exon 4, the IL-6 level in individuals with genotype $\mathrm{CD}$ was significantly higher than that in individuals with 
genotypes CC and DD ( $<<0.05$; Table 3$)$. The IL-2, IL-4, IFN- $\beta$, and IL-10 levels showed no significant differences between the 3 genotypes. With regard to BPI exon 10, the IL-12 level was significantly higher when pigs showed the $A B$ phenotype $(P<0.05$, Table 4$)$.

Table 3. Relationship between different genotypes at the $B P I$ exon 4 site and immune indices (mean $\pm \mathrm{SD}$ ).

\begin{tabular}{lccccrr}
\hline Genotype & \multicolumn{5}{c}{ Immune indexes $(\mathrm{pg} / \mathrm{mL})$} \\
\cline { 2 - 6 } & IL-2 & IL-4 & IL-6 & IFN- $\beta$ & IL-10 & IL-12 \\
\hline CC & $38.78 \pm 16.84$ & $6.53 \pm 1.96$ & $125.11 \pm 34.75^{\mathrm{a}}$ & $9.48 \pm 3.39$ & $21.55 \pm 6.06$ & $31.86 \pm 8.78$ \\
CD & $48.02 \pm 27.79$ & $7.89 \pm 3.57$ & $157.88 \pm 59.75^{\mathrm{b}}$ & $9.24 \pm 5.07$ & $23.55 \pm 8.53$ & $31.73 \pm 9.18$ \\
DD & $33.79 \pm 13.23$ & $6.03 \pm 1.03$ & $99.97 \pm 19.29^{\mathrm{a}}$ & $6.61 \pm 3.36$ & $19.83 \pm 2.44$ & $22.73 \pm 6.97$
\end{tabular}

Different letters in a column indicate significant difference $(\mathrm{P}<0.05)$.

Table 4. Relationship between different genotypes at the $B P I$ exon 10 site and immune indexes (mean $\pm \mathrm{SD}$ ).

\begin{tabular}{lccccrr}
\hline Genotype & \multicolumn{5}{c}{ Immune indexes $(\mathrm{pg} / \mathrm{mL})$} \\
\cline { 2 - 7 } & IL-2 & IL-4 & IL-6 & IFN- $\beta$ & IL-10 & IL-12 \\
\hline AA & $47.02 \pm 24.25$ & $7.50 \pm 3.92$ & $135.43 \pm 56.63$ & $8.46 \pm 4.96$ & $22.37 \pm 8.73$ & $27.79 \pm 7.28^{\mathrm{a}}$ \\
AB & $37.61 \pm 20.23$ & $6.69 \pm 1.93$ & $134.53 \pm 44.34$ & $9.66 \pm 3.82$ & $22.08 \pm 6.46$ & $33.39 \pm 9.42^{\mathrm{b}}$ \\
BB & $48.44 \pm 21.45$ & $7.32 \pm 2.76$ & $140.73 \pm 52.65$ & $8.72 \pm 3.72$ & $22.09 \pm 6.16$ & $29.01 \pm 8.69^{\mathrm{a}}$ \\
\hline
\end{tabular}

Different letters in a column indicate significant difference $(\mathrm{P}<0.05)$.

Based on the effect of a single genotype at the BPI exon 4 or 10 site, we attempted to combine genotypes at the $B P I$ exon 4 and 10 sites to examine the effect of the combined genotypes on the immune indices (Table 5). The combined genotypes showed a significant effect on IL-2, IL-6, and IL-12 levels ( $<<0.05)$. In individuals with the CDAB genotype, IL-6 level was significantly higher than that in individuals with the CCAB genotype $(\mathrm{P}<0.05)$, and the IL-12 level was significantly higher than that in individuals with the DDAA genotype (P $<0.05)$. Overall, the IL- 6 and IL-12 levels for the CDAB genotype were the highest, and thus this combined genotype can be considered superior in terms of disease resistance.

Table 5. Relationship between combined genotypes at BPI exon 4 and 10 sites and immune indices (mean \pm SD).

\begin{tabular}{lcccccc}
\hline Genotype & \multicolumn{5}{c}{ Immune indexes $(\mathrm{pg} / \mathrm{mL})$} \\
\cline { 2 - 7 } & \multicolumn{1}{c}{ IL-2 } & \multicolumn{1}{c}{ IL-4 } & \multicolumn{1}{c}{ IL-6 } & \multicolumn{1}{c}{ IFN- $\beta$} & IL-10 & IL-12 \\
\hline CCAA & $43.71 \pm 3.12^{\text {ab }}$ & $6.03 \pm 1.48$ & $107.25 \pm 1.95^{\text {ab }}$ & $7.35 \pm 1.25$ & $18.19 \pm 6.37$ & $27.60 \pm 2.76^{\text {ab }}$ \\
CCAB & $33.68 \pm 13.23^{\mathrm{a}}$ & $6.20 \pm 1.49$ & $119.59 \pm 22.87^{\mathrm{a}}$ & $10.06 \pm 3.33$ & $21.65 \pm 6.22$ & $33.66 \pm 8.98^{\mathrm{a}}$ \\
CCBB & $48.44 \pm 21.45^{\mathrm{ab}}$ & $7.32 \pm 2.77$ & $140.73 \pm 52.65^{\mathrm{ab}}$ & $8.72 \pm 3.72$ & $22.09 \pm 6.16$ & $29.01 \pm 8.69^{\mathrm{ab}}$ \\
CDAA & $52.04 \pm 27.52^{\mathrm{b}}$ & $8.17 \pm 4.68$ & $150.81 \pm 63.93^{\mathrm{ab}}$ & $9.11 \pm 5.76$ & $23.97 \pm 10.17$ & $29.68 \pm 7.09^{\mathrm{ab}}$ \\
CDAB & $43.27 \pm 28.85^{\mathrm{ab}}$ & $7.35 \pm 2.43$ & $160.52 \pm 61.55^{\mathrm{b}}$ & $8.64 \pm 4.60$ & $22.95 \pm 7.35$ & $34.17 \pm 10.06^{\mathrm{a}}$ \\
DDAA & $32.50 \pm 15.89^{\mathrm{ab}}$ & $6.25 \pm 1.14$ & $102.99 \pm 22.44^{\mathrm{ab}}$ & $7.04 \pm 3.98$ & $19.80 \pm 2.81$ & $21.63 \pm 8.10^{\mathrm{b}}$ \\
\hline
\end{tabular}

Different letters in a column indicate significant difference $(\mathrm{P}<0.05)$.

\section{DISCUSSION}

In our study, one mutation, C522T, at the BPI exon 4 site, and two mutations, $\mathrm{A} 1060 \mathrm{G}$ and $\mathrm{T} 1151 \mathrm{G}$, at the BPI exon 10 site, were detected in Sutai breeds. These mutations differ from those reported in other studies. Cao (2008) reported that 6 SNPs were present in exon 4 
of the BPI gene, including C512T, T551G, C563T, T573C, G599A, and T607C, among which T573C and T607C caused amino acid mutations. Tuggle et al. (2006) reported that one mutation, G599A, in exon 4 of the BPI gene was related to resistance in swine. The difference in results between this study and previous studies may be because of differences in breed or individuals used; therefore, our results need to require further investigation.

With regard to the immune indices, IL-6 levels were found to be significantly higher in pigs with the $C D$ genotype than in pigs with the other 2 genotypes at the $B P I$ exon 4 site, and IL-12 levels in pigs with the AB genotype were significantly higher than in pigs with the other 2 genotypes at the $B P I$ exon 10 site. Because cytokines play a significant role in immune responses in the body, including humoral and cellular immunity, cytokine levels can be used as an accurate physiological index for stress response and resistance. IL-6 is a cytokine with multiple biological activities, a number of which are involved in various aspects of immune and inflammatory responses (Kishimoto and Hirano, 1988). IL-6 is produced by various cell types, such as fibroblasts, macrophages, T and B lymphocytes, endothelial cells, glia cells, and keratinocytes, upon exposure to a variety of extracellular stimuli (Ray et al. 2008). IL-6 is not produced under normal conditions. However, once bacterial and viral infections or tissue injuries occur in the host, IL-6 is expressed rapidly and transiently and participates in host defense. A decrease in the expression of IL-6 in swine lymphocytes leads to continuous immunosuppression (Chen et al., 2010). IL-12 was independently discovered by Kobayashi et al. in 1989 and Stern et al. in 1990 as "natural killer-stimulating factor" and "cytotoxic lymphocyte maturation factor", respectively. IL-12 has the extensive capacity to activate cytotoxic lymphocytes, including Th1-mediated CD4+ cell differentiation, and stimulate the activation of natural killer cells and the production of interferon- $\gamma$ (Shrayer et al., 2002; Yoon et al., 2003), and thus it was considered to be a target gene for bioprevention. Therefore, higher expression of IL-6 or IL-12 contributes to improved general disease resistance in the body. Therefore, pigs with the $\mathrm{CD}$ and $\mathrm{AB}$ genotypes had higher levels of IL-6 and IL-12, respectively, and showed strong stress resistance.

Most economic traits of livestock and poultry are regulated by polygenic sites at different levels. The effect of a single genetic marker is relatively weak, and therefore cannot be directly applied to actual production; thus, it is necessary to consider complex interactions between different sites. The effect of polygenic sites is the additive effect of 1 or more single sites. The effect of combined genotypes is not only likely to be stronger than that of single genotypes (Liu et al., 2009, 2010), but also has no corresponding advantages compared to single genotypes (Chang et al., 2009). Currently, gene polymerization is mainly used to analyze animal growth traits and reproductive performance, for which genetic improvement of livestock and poultry by marker-assisted selection is more useful (Zeng et al., 2011). In our study, the optimal combined genotype at the $B P I$ exon 4 and 10 sites was CDAB, as it resulted in higher IL-6 and IL-12 levels compared to the other combined genotypes. The combined genotype CDAB (the value of IL-6 and IL-12 was 160.52 and $34.17 \mathrm{pg} / \mathrm{mL}$, respectively) was significantly more effective than the CD genotype (the value of IL-6 was $157.88 \mathrm{pg} / \mathrm{mL}$ ), and the AB genotype (the value of IL-12 was $33.39 \mathrm{pg} / \mathrm{mL}$ ), further indicating that combined genotypes were more effective than single genotypes. The effect of combined genotypes should be further examined and validated in a larger population of Sutai pigs, particularly with regard to their role as genetic markers of resistance. Moreover, the immune ability of Sutai pigs resistant to disease should be analyzed by using cytokine and lymphocyte subtype detection to provide a basis for breeding disease-resistant strains of Sutai pigs. 


\section{ACKNOWLEDGMENTS}

Research supported by grants from the National Natural Science Funds (\#31372285, \#31172183), the Science and Technology Supporting Project of Jiangsu Province (\#BE2014357, \#BE2012330, \#BE2013345), and the Priority Academic Program Development of Jiangsu Higher Education Institutions (PAPD).

\section{REFERENCES}

Akin H, Tahan G, Türe F, Eren F, et al. (2011). Association between bactericidal/permeability increasing protein (BPI) gene polymorphism (Lys216Glu) and inflammatory bowel disease. J. Crohns Colitis 5: 14-18.

Christopher KT, Thomas JS, Shi XW and Martha AM (2004). Genetic Markers for Improved Disease Resistance in Animals (BPI). United States, Kind Code: A1, Patent Application: 20040234980, Nov. 25.

Cao XH (2008). The SNPs Analysis of Exon 3 and Exon 4 of BPI Gene in four Pig Breeds. Dissertation for Ph. M., Southwest University.

Chang GB, Zhou Q, Lei LL, Zhang XY, et al. (2009). Genetic analysis of polygene pyramiding in intramuscular fat traits in chicken. China Poultry 31: 25-28.

Chen G, Hua LZ and Zhang SX (2010). Influence of porcine circovirus type 2 and macrophages on the expression of IL-6, IL-10 and their receptors of piglet lymphocytes in vitro. Jiangsu Agric. Sci. 26: 993-998.

Elsbach P (1998). The bactericidal/permeability-increasing protein (BPI) in antibacterial host defense. J. Leukocyte Biol. 64: $14-18$.

Iovine NM, Elsbach P and Weiss J (1997). An opsonic function of the neutrophil bactericidal/permeability increasing protein depends on both its N- and C-terminal domains. Proc. Natl. Acad. Sci. U. S. A. 94: 10973-10978.

Kishimoto T and Hirano T (1988) Molecular regulation of B lymphocyte response. Annu. Rev. Immunol. 6: 485-512.

Kobayashi M, Fitz L, Ryan M, Hewick RM, et al. (1989). Identification and purification of natural killer cell stimulatory factor (NKSF), a cytokine with multiple biologic effects on human lymphocytes. J. Exp. Med. 170: 827-845.

Liu CJ, Zeng YQ, Wei SD, Tang H, et al. (2009). Relationship between the combined genotypes of ESR and FSH $\beta$ genes and reproductive traits in eight pig breeds. Acta Vet. Zootech. Sin. 40: 291-295.

Liu L, Wang J, Zhao QH, Zi C, et al. (2013). Genetic variation in exon 10 of the BPI gene is associated with Escherichia coli F18 susceptibility in Sutai piglets. Gene 523: 70-75.

Liu X, Qiang BYZ, Wang Q, Ling Y, et al. (2010). Effects of multi-genes for reproductive traits in Tibet pig. Hereditas 32: $480-485$.

Ma XJ, Zhang XL, Wang LX and Liu ZP (2011). Studies on difference of immune and production indexes between Songliao black pig and large white pig. China Anim. Husbandry Vet. Med. 38: 52-55.

Mannion BA, Kalatzis ES, Weiss J and Elsbach P (1989). Preferential binding of the neutrophil granule derived bactericidal/permeability increasing protein to target bacteria. J. Immunol. 142: 2807-2812.

Ooi CE, Weiss J, Doerfler ME and Elsbach P (1991). Endotoxin-neutralizing properties of the $25 \mathrm{kD}$ N-terminal fragment and a newly isolated $30 \mathrm{kD} \mathrm{C}$-terminal fragment of the 55-60 kD bactericidal/permeability-increasing protein of human neutrophils. J. Exp. Med. 174: 649-655.

Ray A, Tatter SB, Santhanam U, Helfgott DC, et al. (2008). Regulation of expression of interleukin-6: Molecular studies. Ann. NY Acad. Sci. 557: 353-362.

Shi XW, Mellencamp MA and Tuggle CK (2003). Compete cDNA Cloning and Polymorphisms at Porcine BPI: Associations with Bacterial Load and Immune Response Traits in Pigs. Plant and Animal Genome Conference Proceedings, P231.

Shrayer DP, Bogaars H, Cole B, Wolf SF, et al. (2002). Capacity of murine IL-12 to inhibit the development of primary melanoma tumors and to prevent lung metastases in the melanoma-challenged mice. J. Exp. Ther. Oncol. 2: 93-102.

Stern AS, Podlaski FJ, Hulmes JD, Pan YC, et al. (1990). Purification to homogeneity and partial characterization of cytotoxic lymphocyte maturation factor from human B-lymphoblastoid cells. Proc. Natl. Acad. Sci. U. S. A. 87: 6808-6812.

Tuggle CK, Thomas JS and Shi XW (2006). Genetic Markers for Improved Disease Resistance in Animals (BPI). United States Department of Agriculture. Patent No. US 7070929 B2, 36.

Weiss J, Elsbach P, Olsson I and Odeberg H (1978). Purification and characterization of a potent bactericidal and membrane active protein from the granules of human polymorphonuclear leukocytes. J. Biol. Chem. 253: 2664-2672. 
Yoon TJ, Yoo YC, Kang TB, Song SK, et al. (2003). Antitumor activity of the Korean mistletoe lectin is attributed to activation of macrophages and NK cells. Arch. Pharm. Res. 26: 861-867.

Zeng XC, Chen HY, Jia B, Zhao ZS, et al. (2011). Effects of single and combined genotypes of MC4R and PROP1 genes on growth traits in Chinese merino sheep. Acta Vet. Zootech. Sin. 42: 1227-1232. 